\title{
Nutritional content of Totoaba macdonaldi (Gilbert, 1890), Antioxidants and lipid peroxidation in muscle
}

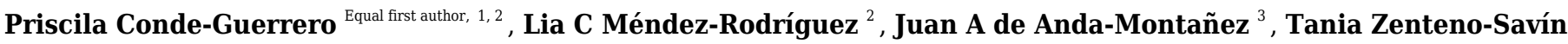 \\ Corresp. Equal first author, 2 \\ 1 Biología Marina, Universidad Autónoma de Baja California Sur, La Paz, Baja California Sur, México \\ 2 Programa de Planeación Ambiental y Conservación, Centro de Investigaciones Biológicas del Noroeste, S.C., La Paz, Baja California Sur, México \\ 3 Programa de Ecología Pesquera, Centro de Investigaciones Biológicas del Noroeste, S.C., La Paz, Baja California Sur, México \\ Corresponding Author: Tania Zenteno-Savín \\ Email address: tzenteno04@cibnor.mx
}

Background. Totoaba, Totoaba macdonaldi, is an endemic species of the Gulf of California, where wide variations in sea temperature throughout the year, surface salinities that gradually increase towards the north, and contamination by discharge of wastewater have been recorded. In addition to the challenges of reproduction and swimming, its characteristic biannual migration presents totoaba with changes in environmental factors that could affect oxidative stress indicators. The objective of this study was to assess spatial and seasonal changes in the oxidative stress indicators in muscle samples of totoaba.

Methods. Reactive oxygen species production, antioxidant enzyme activities and lipid peroxidation levels were quantified by spectrophotometry.

Results. Results suggest spatial-temporal variations of the oxidative stress indicators in muscle of totoaba that may be associated to a complex interaction between environmental and biological factors, including reproduction and nutrient availability. These results contribute to explain the appeal of totoaba as a marketable meat and suggest totoaba may provide antioxidant nutrients to consumers. 
1 Nutritional content of Totoaba macdonaldi (Gilbert, 1890), Antioxidants and lipid

2 peroxidation in muscle.

3

4 Priscila Conde-Guerrero ${ }^{1,3}$, Lia Celina Méndez-Rodríguez ${ }^{1}$, Juan Antonio de Anda-Montañez ${ }^{2}$,

5 Tania Zenteno-Savín ${ }^{1 *}$

6

7 Programa de Planeación Ambiental y Conservación, Centro de Investigaciones Biológicas del

8 Noroeste, S.C., La Paz, Baja California Sur, México.

9 2Programa de Ecología Pesquera, Centro de Investigaciones Biológicas del Noroeste, S.C., La

10 Paz, Baja California Sur, México.

11 B3iología Marina, Universidad Autónoma de Baja California Sur, La Paz, Baja California Sur,

12 México.

13

*Corresponding Author

Tania Zenteno-Savín

Centro de Investigaciones Biológicas del Noroeste, S.C. Instituto Politécnico Nacional 195. Col.

Playa Palo de Santa Rita Sur. La Paz, Baja California Sur. 23096, México

Email address: tzenteno04@,cibnor.mx

\section{ABSTRACT}

Background. Totoaba, Totoaba macdonaldi, is an endemic species of the Gulf of California, where wide variations in sea temperature throughout the year, surface salinities that gradually increase towards the north, and contamination by discharge of wastewater have been recorded. In addition to the challenges of reproduction and swimming, its characteristic biannual migration presents totoaba with changes in environmental factors that could affect oxidative stress indicators. The objective of this study was to assess spatial and seasonal changes in the oxidative stress indicators in muscle samples of totoaba.

Methods. Reactive oxygen species production, antioxidant enzyme activities and lipid peroxidation levels were quantified by spectrophotometry.

Results. Results suggest spatial-temporal variations of the oxidative stress indicators in muscle 
32 factors, including reproduction and nutrient availability. These results contribute to explain the

33 appeal of totoaba as a marketable meat and suggest totoaba may provide antioxidant nutrients to

34

35

36

37 consumers.

\section{Introduction}

Totoaba, Totoaba macdonaldi (Gilbert, 1890), is an endemic species of the Gulf of California, characterized by its longevity and size, reaching up to two meters in length and over $100 \mathrm{~kg}$ body mass (Cisneros-Mata et al., 1997; Guevara, 1990; Román Rodríguez \& Hammann, 1997). Totoaba tend to aggregate for reproduction during the spawning season in the Upper Gulf of California (Flanagan and Hendrickson, 1976; De Anda-Montañez et al., 2013), which renders them vulnerable to fishing. Although commercial fishing of totoaba has been banned for over 40 years by Mexican authorities $(D O F, 2010)$ and international trade is forbidden by international organizations (CITES 2010, IUCN, 2016), the high demand for dried swimming bladders (known as maw) in Asia, particularly in China, with prices that can achieve US\$ 5,000 or more per kilogram, ex-vessel price, has increased the illegal fishing of totoaba with gillnets, mainly in the Upper Gulf of California (Morell, 2017; Valenzuela-Quiñonez et al., 2015). Simultaneously, the bycatch of the critically endangered vaquita (Phocoena sinus) associated with totoaba illegal fishing is an international concern (Morell, 2017) that must be properly addressed in a holistic manner based on scientific information, but that is beyond the scope of this study.

Totoaba is a traditional staple food for people living in coastal towns in the upper Gulf of California. This species has been recently subjected to aquaculture (mariculture) (True, Silva Loera \& Castro Castro, 1997; Juarez, et al., 2016) and is available as a main course in several restaurants in Mexico and the USA (Wright, 2017). Studying the antioxidant defense in wild fish provides a basis of the oxidative state of the fresh product which is later subjected to postmortem handling processes (storage, distribution, or heating during cooking) that promote additional oxidative damage. Totoaba muscle contains an elevated amount of $\Omega-6$ HUFAs; hence it is expected to be susceptible to lipid and protein oxidation, which may affect its organoleptic properties.

Assessing oxidative stress in fish muscle provides valuable information. Reactive oxygen species (ROS) production, antioxidant content and, thus, oxidative damage, in animals, including fish, varies in response to both environmental and physiological factors (Halliwell \& Gutteridge, 
63

64

65

66

67

68

69

2007; Lushchak, 2011b). Sea temperature, dissolved oxygen, salinity, presence of contaminants, photoperiod, among others, are environmental factors that can influence the antioxidant status of fish (Lushchak, 2011b). Nutritional status, physical activity, age, sex, as well as reproduction itself, could also contribute to variations in tissue antioxidant content (Halliwell \& Gutteridge, 2007). Diet, physical activity and reproduction can alter fish metabolism and oxidative stress indicators (Filho, Giulivi \& Boveris, 1993; Aleshko \& Lukyanova, 2008; Birnie-Gauvin et al., 2017). Antioxidants neutralize ROS, contributing to avoid oxidative damage, and thus oxidative stress, in cells and tissues; oxidative stress has been associated to cardiovascular and respiratory diseases, cancer, immune deficiency, some inflammatory conditions, among others (Halliwell \& Gutteridge, 2007). Evidence suggests that including antioxidants in the diet contributes to maintain human health (Kulawik et al., 2013).

Totoaba perform two annual migrations; during summer months the organisms move away from the coast towards deeper and colder waters, and in winter-spring adults swim towards the Colorado River delta to reproduce (Cisneros-Mata, Botsford \& Quinn, 1997; De Anda-Montañez et al., 2013). The Gulf of California is characterized by wide variations in sea temperature throughout the year, high surface salinities that gradually increase towards the north, and contamination by discharge of wastewater, particularly in the upper Gulf of California. Therefore, totoaba is faced with seasonal and spatial changes in both environmental and biological factors throughout its lifespan which affect the quality of their muscle. Muscle is the main fish tissue consumed by humans. The aim of this study was to analyze and compare the antioxidant enzyme activities and lipid peroxidation levels in muscle of totoaba collected in different sites and seasons along its migratory route, towards assessing the potential variation in nutritional content depending on the season and location the fish was caught.

\section{Materials \& Methods}

\section{Overview of experimental study}

Totoaba macdonaldi organisms were collected according to a stratified random sampling during 11 field trips in different locations and dates around the Gulf of California (Figure 1). From each specimen, muscle samples were dissected, frozen, and transported to the laboratory, where they were kept frozen until analyzed. 
94

95

96

97

98

99

100

101

102

103

104

105

106

107

108

109

110

111

112

113

114

115

116

117

118

119

120

121

122

123

124

\section{Sample collection and preparation}

Totoaba were collected from the Upper Gulf of California in the three types of habitats (estuarine, Upper Gulf of California and Colorado River Delta Biosphere Reserve; rocky, area around Consag and Las Encantadas Islands; continental, along the coasts of Sonora and Sinaloa) where the fish inhabit (Figure 1). Field trips were conducted in April, May, and November of 2010; February, March, October, November, and December of 2011; April 2012; and January, February of 2013 to collect samples during all seasons. Totoaba were found in the estuarine habitat (spawning grounds; De Anda-Montañez et al., 2013) in winter and spring, in the coastal and rocky habitats (feeding areas; De Anda-Montañez et al., 2013) in autumn, but were not found in any of the sampled sites in summer. In summer, when sea surface temperatures in the Gulf of California can be over $28^{\circ} \mathrm{C}$, totoaba migrate to deeper $(\sim 70 \mathrm{~m})$ colder $\left(\sim 21^{\circ} \mathrm{C}\right)$ zones (Hernández-Tlapale et al., 2020) being, thus, inaccessible to fishing gear. Fishes were caught with an empirical gill net (built following the knowledge and experience of the fishermen) of approximately $120 \mathrm{~m}$ long, $4 \mathrm{~m}$ wide (depth) and 10" mesh opening, as well as with individual fishing rods with number 5 hook. Once obtained, weight and length were recorded, and the fish was dissected. Sex was identified by histological criteria (De Anda-Montañez et al., 2013). Organisms that presented gonadal development from stage III of their reproductive cycle were classified as mature (De Anda-Montañez et al., 2013). Those cases in which gonadic development did not allow for sex determination were grouped as undifferentiated. Data were grouped according to habitat (estuarine, rocky, continental), collection date (spring, autumn, winter), and sex and stage of reproductive maturity (immature females (FI), mature females (FM), immature males (MI), mature males (MM) and undifferentiated (U)). Sampling was performed under scientific collection permits issued by the Mexican government (SGPA/DGVS/02913/10, SGPA/DGVS/05508/11 and SGPA/DGVS/00039/13), as described in the research protocol of the project entitled "Health and Conservation status of the totoaba population (Totoaba macdonaldi) in the Gulf of California: a critically endangered species" (CONABIO: FB1508/HK050/10; CONACYT 2011-01/165376), and according to the institutional ethical guidelines for critically endangered species (CIBNOR, SGPA/DGVS, CONABIO, CONACYT).

All muscle samples $(n=174)$ collected were immediately frozen by immersion in a 10-liter cryoshipper (Thermo Fisher Scientific, Waltham, MA, USA) with liquid nitrogen and 
125 transported to the Oxidative Stress Laboratory at CIBNOR, La Paz, Baja California Sur, Mexico,

126 where they were kept frozen $\left(-80^{\circ} \mathrm{C}\right)$ until the corresponding analyses were performed. From

127 each muscle sample, $100 \mathrm{mg}$ of tissue was taken and homogenized (50 mM phosphate buffer, $\mathrm{pH}$

$1287.5,1 \mathrm{mM}$ phenylmethylsulfonyl fluoride (PMSF)). The homogenized samples were centrifuged

129 for $15 \mathrm{~min}$ at $2124 \times \mathrm{g}$ and the supernatants obtained were immediately analyzed. The reagents

130 used were obtained from Sigma-Aldrich Chemical Co. (San Luis, MO) and Bio-Rad

131 Laboratories (Hercules, CA).

132

133 Superoxide radical production

134 Superoxide radical $\left(\mathrm{O}_{2}{ }^{\circ-}\right)$ production was analyzed as an indicator of ROS production according

135 to Drossos et al. (1995), based on its production rate during the reduction of ferricytochrome c.

136 Muscle samples were placed in Krebs buffer $\left(0.11 \mathrm{M} \mathrm{NaCl}, 0.0047 \mathrm{M} \mathrm{KCl}, 0.012 \mathrm{M} \mathrm{MgSO}_{4}\right.$,

$1370.012 \mathrm{M} \mathrm{NaH}_{2} \mathrm{PO}_{4}, 0.025 \mathrm{M} \mathrm{NaHCO}_{4}$ and $0.001 \mathrm{M}$ glucose $)$. Cytochrome c $(15 \mu \mathrm{M})$ was added

138 to each sample, which was incubated at $37^{\circ} \mathrm{C}$ in a rocking shaker for 15 minutes. N-

139 ethylmaleimide $(3 \mathrm{mM})$ was added to stop the reduction of cytochrome c. Samples were

140 centrifuged at $2124 x g$ at $4^{\circ} \mathrm{C}$ for 10 minutes and the supernatant was transferred to a cell to

141 measure the absorbance in a spectrophotometer (Beckman Coulter DU 800 UV / Visible,

142 Fullerton, CA) at $550 \mathrm{~nm}$ wavelength. All samples were analyzed in triplicate. The production of

$143 \mathrm{O}_{2}^{--}$was calculated based on the extinction coefficient $\mathrm{E}_{550}=21 \mathrm{nM} \mathrm{L}^{-1} \mathrm{~cm}^{-1}$. Superoxide radical

144 production data were expressed in nmol per min per mg of protein.

145

146

Lipid peroxidation

147 Lipid peroxidation levels were evaluated as an indicator of oxidative damage and meat quality

148 following the method described by Persky et al. (2000). Lipid peroxidation was analyzed as the

149 content of thiobarbituric acid reactive substances (TBARS). A standard curve was prepared with

150 a solution of 1,1,2,3-tetraethoxypropane (TEP) in a range of 0 to $5 \mathrm{nmoles} 250 \mu \mathrm{L}^{-1}$. The samples

151 and the standard curve were incubated at $37^{\circ} \mathrm{C}$ with constant agitation for $15 \mathrm{~min}$. Upon

152 completion, trichloroacetic acid (TCA, $0.76 \mathrm{M}$ in $1 \mathrm{M} \mathrm{HCl}$ ) was added to stop the reaction.

153 Thiobarbituric acid (TBA, 1\%) was added and the tubes were incubated at $90^{\circ} \mathrm{C}$ for $10 \mathrm{~min}$ in a

154 constant shaking water bath. Subsequently, they were placed in an ice bath and centrifuged (2124

$155 x \mathrm{~g}$ ) for $10 \mathrm{~min}$ at $4^{\circ} \mathrm{C}$. The supernatant was recovered, and absorbance was read in a 
156 spectrophotometer at $530 \mathrm{~nm}$ wavelength. All samples were analyzed in triplicate. The results

157 were calculated from the standard curve and expressed in nanomoles of TBARS per mg of

158 protein.

159

160

\section{Antioxidant enzymatic activity}

161

Superoxide dismutase (SOD, E.C.1.15.1.1) activity was measured by calculating the inhibition of

162 nitroblue tetrazolium (NBT) reduction and expressed in units of SOD per mg of protein according to the method of Suzuki (2000). One unit of SOD activity is defined as the amount of enzyme needed to inhibit $50 \%$ of the maximum reaction of $\mathrm{O}_{2}{ }^{--}$with NBT. SOD activity is expressed in $\mathrm{U} \mathrm{mg}^{-1}$ protein. Catalase (CAT, E.C.1.11.1.6) activity was quantified by following the decrease of hydrogen peroxide $\left(\mathrm{H}_{2} \mathrm{O}_{2}\right)$ content at $240 \mathrm{~nm}$ wavelength $($ Aebi, 1984) and was expressed in units of CAT per mg of protein. One unit of CAT activity is defined as the amount of enzyme that catalyzes the decomposition of $1 \mu \mathrm{mol}$ of $\mathrm{H}_{2} \mathrm{O}_{2}$ per minute. CAT activity is expressed in $\mathrm{U} \mathrm{mg}^{-1}$ protein. Glutathione peroxidase (GPx, E.C.1.11.1.9) activity was measured according to Flohé \& Günzler (1984), this method uses $\mathrm{H}_{2} \mathrm{O}_{2}$ as a substrate coupled with the oxidation of nicotinamide adenine dinucleotide phosphate (NADPH) catalyzed by glutathione reductase (GR) at $240 \mathrm{~nm}$ wavelength. One unit of GPx is defined as the amount of enzyme that oxidizes $1 \mu \mathrm{mol}$ of NADPH per minute. The activity of GR (E.C. 1.6.4.2) was measured by following the decreasing levels of NADPH according to the method of Goldberg \& Spooner (1983). Results were expressed in units of GR per mg of protein. One unit of GR is defined as the amount of enzyme that oxidizes $1 \mu \mathrm{mol}$ of NADPH per minute. The enzymatic activity of glutathione S-transferase (GST, E.C.2.5.1.18) was determined following the formation of the thioether product in the reaction between glutathione and 1-chloro, 2,4-dinitrobenzene (CDNB) according to the method of Habig \& Jakoby (1981). Enzymatic activity was expressed in units of GST per mg of protein. One unit of GST activity is defined as the amount of enzyme that catalyzes the conjugation of $1 \mu \mathrm{mol}$ of CDNB per minute at $25^{\circ} \mathrm{C}$. All samples were analyzed in triplicate.

\section{Soluble proteins}

To standardize the enzymatic activities, the concentration of proteins present in the tissue extract was quantified following the method of Bradford (1976) using commercial kits (BioRad $\left.{ }^{\circledR}\right)$. 
187 Samples were diluted 1:50 with phosphate buffer (50 mM, pH 7.5, EDTA). A standard curve of

188 bovine serum albumin (BSA) was prepared in a concentration range of $0-2 \mathrm{mg} \mathrm{mL}^{-1}$. In a 189 microplate, distilled water $\left(\mathrm{dH}_{2} \mathrm{O}\right)$, Bradford dye and the BSA standard curve or sample were 190 added to each well. In addition, a blank was prepared with $\mathrm{dH}_{2} \mathrm{O}$ and Bradford dye only. After 15 191 minutes, the absorbance at $620 \mathrm{~nm}$ wavelength was read on the microplate reader (Multiskan FC, 192 Thermo Scientific, Finland). All samples were analyzed in triplicate. The protein content in each

193 sample was calculated based on the regression of the standard curve. Data are expressed in mg of 194 protein per $\mathrm{mL}$.

195

196 Statistical analysis

197 Tests were performed to determine if the dataset follows the assumptions of normality and 198 homoscedasticity. Non-parametric Kruskal-Wallis tests were applied to determine significant differences in $\mathrm{O}_{2}{ }^{--}$production rate, TBARS levels and antioxidant enzyme activities between seasons, habitats, and sex/maturity stage. The significance level $(\alpha)$ of $5 \%(p=0.05)$ was taken to denote statistical differences for all tests. The statistical analyses were performed with STATISTICA $^{\circledR}$ (StatSoft, Inc., 2002). Two generalized linear models (GLMs) were created to identify the variables with the greatest contribution to the variability of oxidative damage, as a proxy for meat quality, in totoaba muscle samples. Each model was developed according to the activity of each specific enzyme. Superoxide radical $\left(\mathrm{O}_{2}{ }^{--}\right)$production rate and lipid peroxidation (TBARS) levels were selected as the continuous dependent variables (response); while season, habitat and sex/maturity stage were considered the categorical explanatory variables, and the activity of each enzyme was included as a continuous explanatory variable (Table 1). The models assumed the Gamma distribution because it yielded the best fit, as it was not significantly different from the Chi-square test ( $p<$ 0.05). The link function used in all models was $\log$. The models were built using a forward

212 procedure, that is, explanatory variables were added to the null model, and the best model was selected based on Akaike's information criterion (AIC), bayesian information criterion (BIC) and residual deviance $(\mathrm{RD})$. This selection process was repeated for both models, the superoxide radical $\left(\mathrm{O}_{2}{ }^{--}\right)$production rate and lipid peroxidation (TBARS) levels. The models were validated by visual analysis of the residuals and observed/predicted values. The best model for each biomarker was selected based on AIC. 


\section{Results}

220 A total of 174 totoaba individuals were analyzed. Of these, 64 were FI, 25 FM, 54 MI, 21 MM

221 and $10 \mathrm{U}$. Comparisons of the antioxidant enzyme activities and oxidative damage levels were

222 made between the different habitats, seasons, and sex/maturity stage (Table 2). Not all

223 sex/maturity stage categories were found in all seasons, nor habitats, perhaps due to the

224 combination of the species migratory (horizontal and vertical) behavior and the specific

225 environmental conditions at each site and season (Figure 2). In the estuaries, higher $\mathrm{O}_{2}{ }^{-}$

226 production rate and lower activities of CAT, GPx and GST were observed for the FM in winter

227 compared to spring $(p<0.05)$. No significant differences were observed in TBARS levels $(p>$

228 0.05). In the rocky habitat, higher TBARS levels and GPx activity, as well as lower SOD

229 activity, were observed for the FI in the spring compared to autumn $(p<0.05)$. In the continental

230 habitat, higher GST activity was observed for the MI in winter than in autumn $(p<0.05)$. In

231 spring, the FM had higher GST activity, while the MM had lower $\mathrm{O}_{2}{ }^{-}$production rate and higher

232 GPx activity in the estuaries than in the rocky areas $(p<0.05)$. In autumn, both the MI and U

233 totoaba had higher GST activity in the rocky areas as compared to the continental areas $(p<$

234 0.05). In winter, the FI had lower $\mathrm{O}_{2}{ }^{--}$production rate and higher GPx activity in the estuaries

235 than in the rocky areas $(p<0.05)$, while MI had lower antioxidant enzyme activities in the

236 estuaries than in the continental areas $(p<0.05)$. The FI had higher GPx activity than the FM

237 totoaba in spring and lower GST activity than the U totoaba in autumn in the rocky areas ( $p<$

238 0.05). The MI had higher GST activity than the U totoaba in autumn and higher TBARS levels,

239 and GR and GST activities than FI totoaba in winter in the continental areas $(p<0.05)$.

240 The results of the selection process and the parameters obtained for the GLMs for $\mathrm{O}_{2}{ }^{--}$production

241 rate and TBARS levels are shown in Tables 3 and 4, respectively. The best-fit model selected

242 based on AIC and BIC to explain the $\mathrm{O}_{2}{ }^{--}$production rate included enzymatic (GR and SOD)

243 activity, the habitat (estuarine, rocky and continental areas), as well as the season (spring,

244 autumn and winter). This model started with ten parameters $(\mathrm{k}=9)$, but only six of these $(\mathrm{k}=6)$,

245 intercept, GR and SOD activities, estuarine and rocky areas, and spring, as well as the interaction

246 between habitat and season, were significant $(p<0.05)$ in explaining the $\mathrm{O}_{2}{ }^{*-}$ production rate.

247 The best model selected based on AIC and BIC for lipid peroxidation (TBARS) levels included

248 enzymatic (GST, CAT, SOD and GPX) activity and season (spring, autumn and winter). This 
249 model started with nine parameters $(\mathrm{k}=8)$, but only four $(\mathrm{k}=4)$, intercept, SOD, spring and 250 autumn, significantly contributed to explain the variation in TBARS levels. In addition, the best251 fit model for each indicator was validated using analysis of residuals (Figure 3), which suggests

252 that the variance of the residuals is homogeneous over the independent variables in the models;

253 thus, confirming that the models fit the data reasonably well.

254

255

256

\section{Discussion}

The spatial-temporal variation of the oxidative stress indicators in fish suggests a complex interaction between different environmental and biological factors (Wilhelm-Filho et al., 2001; Kopecka \& Pempkowiak, 2008; Aras et al., 2009; Radovanović et al., 2010; Pavlović et al., 2010). Results from this study suggest that the relative antioxidant content and oxidative damage may vary depending on the geographic location and the season when the products are obtained due to the variation in conditions wild totoaba, T. macdonaldi, face along its distribution. Furthermore, these indicators provide relevant information about fish product quality, and may be an important reference for human health (Tripathy, 2016). Fish products are at risk of quality loss due to oxidation; lipid peroxidation can lead to a rancid taste and development of many compounds that may cause adverse effects to human health (Tripathy, 2016). Some peroxidation products, including aldehydes, can react with specific amino acids and form carbonyls and other protein aggregates. These secondary products may cause additional nutritional loss (Ahmed et al., 2016). Higher $\mathrm{O}_{2}{ }^{-*}$ production rate and lower activities of CAT, GPx and GST were observed in winter compared to spring in muscle samples of the FM totoaba collected in estuaries. Reduced activity of antioxidant enzymes has been reported at low temperatures (Viarengo et al., 1991; Speers-Roesch \& Ballantyne, 2005;

272 Lushchak, 2011a). In the Upper Gulf of California, the sea surface temperature has a wide range of variation and can decrease to $10^{\circ} \mathrm{C}$ in winter (Soto-Mardones, Marinone \& Parés-Sierra, 1999). Low temperature in winter could be associated to the lower antioxidant enzyme activities in the muscle of FM totoaba in this study. Active swimming, associated with migration in some species, can also contribute to increased ROS production due to increased oxygen consumption by red muscle mitochondria (Costantini,

278 2008; Amérand et al., 2010; Mortelette et al., 2010; Wilson et al., 2014). Totoaba is a migratory species with markedly seasonal reproduction; that is, the development of the gonads begins 
280 during the winter and continues during spring (De Anda-Montañez et al., 2013). During the

281 months of March and April, the largest number of brood stock is reported in the estuaries;

282 therefore, an increase in $\mathrm{O}_{2}{ }^{*}$ production rate could be expected in totoabas in estuarine areas,

283 assuming that they have a larger metabolic activity. However, lower $\mathrm{O}_{2}{ }^{*-}$ production rate and

284 GPx activity were observed in muscle samples of the MM totoabas in the estuaries during spring,

285 as compared to the rocky habitat. It is possible that, during the reproductive season, most of the

286 resources (energy, nutrients, antioxidant defenses, etc.) are diverted preferentially to the gonads;

287 under these circumstances (lower availability of resources for maintenance), other tissues, such

288 as muscle, may become susceptible to oxidative stress and potential loss of meat quality

289 (Wiersma et al., 2004; Smith et al., 2014).

290 The FI totoabas at the rocky habitat had higher TBARS levels and GPx activity, but lower SOD

291 activity, in spring as compared to autumn. Because these are immature fish, the observed

292 differences may be associated to diet and nutrition. During winter and spring, higher primary

293 productivity has been reported in the northern part of the Gulf of California (Pérez-Arvizu,

294 Aragón-Noriega \& Espinosa-Carreón, 2013); which suggests greater food abundance and

295 diversity for the organisms that live there, including totoaba. Although juvenile totoaba consume

296 diets with high protein levels and moderate lipid content, their natural diet seems to be rich in $\Omega$ -

2973 and $\Omega-6$ highly unsaturated fatty acids (HUFAs) (López et al., 2006). An increase in lipid

298 content increases the potential for generation of lipid radicals and, thus, the susceptibility to

299 oxidation, as has been reported for fish and sea urchins (Malanga et al., 2007; Zhang et al.,

300 2007). Although no differences were observed in the $\mathrm{O}_{2}{ }^{--}$production rate in FI totoabas in this

301 study, other ROS not quantified in this study, such as $\mathrm{H}_{2} \mathrm{O}_{2}$, could contribute to lipid

302 peroxidation; this would coincide with the antioxidant enzyme activities observed in FI totoabas.

303 Fish products are an important part of a healthy diet, as they are sources of several nutrients,

304 including antioxidants. Increasing evidence of the benefits of dietary antioxidants in human

305 health include lowering the risk of some cardiovascular diseases, aging and even cancer

306 (Kulawik et al., 2013). The levels of endogenous antioxidant enzymes contribute to maintain the

307 fish meat quality, to prolong shelf-life of products and to decrease the health risks from oxidation

308 to the fish, the fish products, and consumers (Sen \& Mandal, 2016).

309 The TBARS levels, as well as GPx and GST activities were higher in the MI compared to the FI

310 in winter in the continental habitat. This relative difference could be attributed to antioxidant 
311 defenses not quantified in this study, such as vitamin A, vitamin C, vitamin E, carotenoids,

312 glutathione, flavonoids, or estrogens (Viña et al., 2005; Amérand et al., 2010). However, these

313 differences between sexes should not be generalized, since no differences were observed

314 between FI and MI in other seasons or habitats, (e.g., estuaries), nor between sexes for mature

315 organisms.

316 Higher activity of SOD, CAT, GPx, GR and GST was observed in fish from the continental

317 habitat as compared to those in the estuaries during winter in MI totoaba. This may be a response

318 to environmental changes due to the upwelling phenomenon that occurs on the eastern coast of

319 the Gulf of California in winter, which implies a cooler, nutrient-rich water transport to the

320 surface (Lavín \& Marinone, 2003; Pérez-Arvizu, Aragón-Noriega \& Espinosa-Carreón, 2013).

321 The greater availability of nutrients in the water column has been associated to greater food

322 availability and fish nutritional status. It is possible that the increased activity of all the

323 antioxidant enzymes quantified in MI totoaba in this study is a response to the increased

324 metabolic rate that could be implied by the greater food availability. Alternatively, the variations

325 in the activity of the antioxidant enzymes observed in the present study could be due to other

326 environmental factors, such as pollution. Greater GST activity was observed in the muscle

327 samples of the (MI, U) totoabas in the rocky habitat compared to those in the continental habitat

328 in the autumn. GST participates in the detoxification of a number of xenobiotic compounds and

329 its increased activity has been reported in many fish species (Porte et al., 2000; Lopes et al.,

330 2001; Napierska \& Podolska, 2005; Kopecka \& Pempkowiak, 2008). It has been suggested that

331 the main entry of contaminants (organochlorine pesticides, trace elements) into the Upper Gulf

332 of California is the discharge of wastewater from the agricultural valleys of Mexicali and San

333 Luis Río Colorado in the delta area. Shumilin et al. (2002) reported an intense resuspension of

334 sediments in the delta with a subsequent transport to the south; the concentrations of most of the

335 elements studied are higher in the southwest margin of the Upper Gulf. Possibly, the tidal

336 processes that cause the transport of sediments towards the south could also participate in the

337 transport of other pollutants.

338 The results of the GLM analyses suggest that the variables that best explained the variability of

339 the oxidative damage in muscle of totoaba are the antioxidant enzyme activities, habitat

340 (specifically, the rocky area of the Consag and Las Encantadas Islands) and season (spring). It is

341 possible that the variation in $\mathrm{O}_{2}{ }^{*}$ - production rate and TBARS levels were related to the 
342 environmental changes that occur along the Gulf of California, spatially and temporarily.

343 Extreme environmental conditions occur in the northern Gulf of California, especially the delta 344 area. Variations in the oxidative stress indicators in response to changes in biotic and abiotic 345 factors have been previously reported in several fish species (Aras et al., 2009; Pavlović et al., 346 2010; Oliva et al., 2012), including T. macdonaldi (Hernández-Aguilar et al., 2017). Results 347 from this study suggest that totoaba faces spatial-temporal variation in muscle oxidative stress 348 indicators that may be associated to a complex interaction between environmental and biological 349 factors, including food availability and temperature.

350

\section{Conclusions}

352 Studying the antioxidant defense in wild fish provides a basis of the oxidative state of the fresh 353 product which is later subjected to post-mortem handling processes (storage, distribution, or 354 heating during cooking) that promote additional oxidative damage. Results from this study 355 suggest spatial-temporal variations of the oxidative stress indicators in muscle of totoaba that 356 may be associated to a complex interaction between environmental (habitat type, potentially 357 pollution) and biological (reproduction, nutrient availability) factors. Furthermore, these results

358 contribute to explain the appeal of totoaba as a marketable meat and suggest totoaba may provide 359 antioxidant nutrients to consumers.

360

361

362

\section{Acknowledgments}

Authors acknowledge L. Campos Dávila, N.O. Monroy Olguín, J.J. Ramírez Rosas, L. Rivera 363 Rodríguez, F. Valenzuela Quiñonez, O. Rodríguez García, H. Bervera León, M. Román Lugo for their assistance with sample collection and/or sample and data processing. Fishermen Federation from San Felipe and Golfo de Santa Clara provided assistance with field work.

\section{References}

Aebi H. 1984. Catalase in vitro. Methods in enzymology 105:121-6. Foods. Sarhad Journal of Agriculture 32:230-238. DOI: 
373

374

375

376

377

378

379

380

381

382

383

384

385

386

387

388

389

390

391

392

393

394

395

396

397

398

399

400

401

402

403

Aleshko SA, Lukyanova ON. 2008. Seasonal variations of biotransformation and antioxidant parameters in liver of the smooth flounder Liopsetta pinnifasciata from Amursky Bay (Sea of Japan). Russian Journal of Marine Biology 34:135-138. DOI: 10.1134/S1063074008020089.

Amérand a., Vettier A, Moisan C, Belhomme M, Sébert P. 2010. Sex-related differences in aerobic capacities and reactive oxygen species metabolism in the silver eel. Fish Physiology and Biochemistry 36:741-747. DOI: 10.1007/s10695-009-9348-0.

Aras NM, Bayir A, Sirkecioglu AN, Bayir M, Aksakal E, Haliloglu HI. 2009. Seasonal changes in antioxidant defence system of liver and gills of Salmo trutta caspius, Salmo trutta labrax and Salmo trutta macrostigma. Journal of Fish Biology 74:842-856. DOI: 10.1111/j.10958649.2008.02164.x.

Arvizu-Martinez J. 1987. Fisheries activities in the Gulf of California, Mexico.

Birnie-Gauvin K, Costantini D, Cooke SJ, Willmore WG. 2017. A comparative and evolutionary approach to oxidative stress in fish: A review. Fish and Fisheries 18:928-942. DOI: 10.1111/faf.12215.

Bradford MM. 1976. A rapid and sensitive method for the quantitation of microgram quantities of protein utilizing the principle of protein-dye binding. Analytical Biochemistry 72:248254. DOI: 10.1016/0003-2697(76)90527-3.

Cisneros-Mata MA, Botsford LW, Quinn JF. 1997. Projecting viability of Totoaba macdonaldi, a population with unknown age-dependent variability. Ecological Applications 7:968-980.

CITES. 2010. Review of CITES Appendixes Based on Resolution Conf. 9.24 (Rev.) Totoaba macdonaldi (Mexican seabass). http://www. cites.org/common/com/AC/17/E17i-06.pdf

Costantini D. 2008. Oxidative stress in ecology and evolution: lessons from avian studies. Ecology Letters 11:1238-1251. DOI: 10.1111/j.1461-0248.2008.01246.x.

De Anda-Montañez JA, García de León FJ, Zenteno-Savín T, Balart-Paez, E., MéndezRodríguez, L. C., Bocanegra-Castillo N, Martínez-Aguilar S, Campos-Dávila L, Román Rodríguez, M. J., Valenzuela-Quiñonez, F., Rodríguez-Jaramillo ME, Meza-Chávez ME, Ramírez-Rosas JJ, Saldaña-Hernández IJ, Olguín-Monroy NO, Martínez-Delgado ME. 2013. Estado de salud y estatus de conservación de la(s) población(es) de totoaba (Totoaba macdonaldi) en el Golfo de California: una especie en peligro de extinción. La Paz, Baja California Sur. 
404

405

406

407

408

409

410

411

412

413

414

415

416

417

418

419

420

421

422

423

424

425

426

427

428

429

430

431

432

433

434

DOF 2010. Norma Oficial Mexicana. NOM-059-SEMARNAT-2010. Protección ambientalEspecies nativas de México de flora y fauna silvestres-Categorías de riesgo y especificaciones para su inclusión, exclusión o cambio-Lista de especies en riesgo. Secretaría de Gobernación, Mexico City, Mexico http://dof.gob.mx/nota_detalle.php?codigo $=5173091 \&$ fecha $=30 / 12 / 2010$

Drossos G, Lazou A, Panagopoulos P, Westaby S. 1995. Deferoxamine cardioplegia reduces superoxide radical production in human myocardium. The Annals of Thoracic Surgery 59:169-172. DOI: http://dx.doi.org/10.1016/0003-4975(94)00726-N.

Filho DW, Giulivi C, Boveris A. 1993. Antioxidant defences in marine fish-I. Teleosts. Comparative Biochemistry and Physiology Part C: Pharmacology, Toxicology and Endocrinology 106:409-413. DOI: 10.1016/0742-8413(93)90154-D.

Findley L. 2010.Totoaba macdonaldi. Available at https://dx.doi.org/10.2305/IUCN.UK.20103.RLTS.T22003A9346099.en (accessed September 4, 2020).

Flanagan CA, Hendrickson JR. 1976. Observations on the commercial fishery and reproductive biology of the totoaba Cynoscion macdonaldi in the northern Gulf of California Mexico. Fishery Bulletin (Washington D C) 74(3): 531-544 74:531-544.

Flohé L, Günzler WA. 1984. Assays of glutathione peroxidase. In: Methods in enzymology. 114120. DOI: 10.1016/S0076-6879(84)05015-1.

Goldberg DM, Spooner RJ. 1983. Assay of Glutathione Reductase. In: Bergmeyen HV ed. Methods of Enzymatic Analysis. Deerfiled Beach: Verlog Chemie, 258-265.

Guevara JCB. 1990. The conservation of Totoaba macdonaldi (Gilbert), (Pisces: Sciaenidae), in the Gulf of California, Mexico. Journal of Fish Biology 37:201-202. DOI: 10.1111/j.10958649.1990.tb05038.x.

Habig WH, Jakoby WB. 1981. Glutathione S-transferases (rat and human). In: Methods in Enzymology. Elsevier, 218-231. DOI: 10.1016/S0076-6879(81)77029-0.

Halliwell B, Gutteridge JMC. 2007. Free Radicals in Biology and Medicine. New York: Oxford University Press.

Hernández-Aguilar SB, Zenteno-Savin T, De-Anda-Montañez JA, Méndez-Rodríguez LC. 2017. Temporal variation in oxidative stress indicators in liver of totoaba (Totoaba macdonaldi) Perciformes: Sciaenidae. Journal of the Marine Biological Association of the United Kingdom:1-12. DOI: 10.1017/S0025315416001909. 
435 Hernández-Tlapale C, De Ana-Montañez JA, Trasviña-Castro A, Valenzuela-Quiñonez F, 436 Ketchum JT, Muhlia-Melo A. 2020. First record of vertical movements of the totoaba 437 (Totoaba macdonaldi) as evidenced by pop-up satellite tags in the Upper Gulf of https://doi.org/10.1017/S0025315419001188

IUCN 2016. The IUCN red list of threatened species: 2015-14. www.iucnredlist.org (Accessed 9 May 2016)

Juarez LM, Konietzko PA, Schwartz MH. 2016. Totoaba aquaculture and conservation: Hope for an endangered fish from Mexico's Sea of Cortez. World Aquaculture 47:30-38.

Kopecka J, Pempkowiak J. 2008. Temporal and spatial variations of selected biomarker activities in flounder (Platichthys flesus) collected in the Baltic proper. Ecotoxicology and Environmental Safety 70:379-391. DOI: 10.1016/j.ecoenv.2007.05.017.

Kulawik P, Özogul F, Glew R, Özogul Y. 2013. Significance of Antioxidants for Seafood Safety and Human Health. Journal of Agricultural and Food Chemistry 61:475-491. DOI: $10.1021 / \mathrm{jf304266s.}$

Lavín MF, Marinone SG. 2003. An Overview of the Physical Oceanography of the Gulf of California. In: Nonlinear Processes in Geophysical Fluid Dynamics. Dordrecht: Springer Netherlands, 173-204. DOI: 10.1007/978-94-010-0074-1_11.

Lopes PA, Pinheiro T, Santos MC, Da Luz Mathias M, Collares-Pereira MJ, Viegas-Crespo AM. 2001. Response of antioxidant enzymes in freshwater fish populations (Leuciscus alburnoides complex) to inorganic pollutants exposure. Science of the Total Environment 280:153-163. DOI: 10.1016/S0048-9697(01)00822-1.

López LM, Durazo E, Rodríguez-Gómez A, True CD, Viana MT. 2006. Nota de Investigación / Research Note Composición proximal y perfil de ácidos grasos de. Ciencias Marinas 32:303-309.

Lushchak VI. 2011a. Adaptive response to oxidative stress: Bacteria, fungi, plants and animals. Comparative Biochemistry and Physiology Part C: Toxicology \& Pharmacology 153:175190. DOI: $10.1016 /$ j.cbpc.2010.10.004.

Lushchak VI. 2011b. Environmentally induced oxidative stress in aquatic animals. Aquatic Toxicology 101:13-30. DOI: 10.1016/j.aquatox.2010.10.006.

Malanga G, Estevez MS, Calvo J, Abele D, Puntarulo S. 2007. The effect of seasonality on 
466

467

468

469

470

471

472

473

474

475

476

477

478

479

480

481

482

483

484

485

486

487

488

489

490

491

492

493

494

495

496

oxidative metabolism in Nacella (Patinigera) magellanica. Comparative Biochemistry and Physiology - A Molecular and Integrative Physiology 146:551-558. DOI: 10.1016/j.cbpa.2006.01.029.

Morell V. 2017. World's most endangered marine mammal down to 30. Science, 355: 558-559. http://www.ncbi.nlm.nih.gov/pubmed/28183919

Mortelette H, Moisan C, Sébert P, Belhomme M, Amérand A. 2010. Fish as a model in investigations about the relationship between oxygen consumption and hydroxyl radical production in permeabilized muscle fibers. Mitochondrion 10:555-558. DOI: 10.1016/j.mito.2010.05.002.

Napierska D, Podolska M. 2005. Biomarkers of contaminant exposure: results of a field study with flounder (Platichthys flesus) from the southern Baltic Sea. Marine Pollution Bulletin 50:758-767. DOI: 10.1016/j.marpolbul.2005.02.007.

Oliva M, José Vicente J, Gravato C, Guilhermino L, Dolores Galindo-Riaño M. 2012. Oxidative stress biomarkers in Senegal sole, Solea senegalensis, to assess the impact of heavy metal pollution in a Huelva estuary (SW Spain): Seasonal and spatial variation. Ecotoxicology and Environmental Safety 75:151-162. DOI: 10.1016/j.ecoenv.2011.08.017.

Pavlović SZ, Borković-Mitić SS, Radovanović TB, Perendija BR, Despotović SG, Gavrić JP, Saičić ZS. 2010. Seasonal Variations of the Activity of Antioxidant Defense Enzymes in the Red Mullet (Mullus barbatus 1.) from the Adriatic Sea. Marine Drugs 8:413-428. DOI: 10.3390/md8030413.

Pérez-Arvizu EM, Aragón-Noriega EA, Espinosa-Carreón TL. 2013. Variabilidad estacional de la clorofila a y su respuesta a condiciones El Niño y La Niña en el Norte del Golfo de California. Revista de biología marina y oceanografia 48:131-141. DOI: 10.4067/S071819572013000100011.

Persky AM, Green PS, Stubley L, Howell CO, Zaulyanov L, Brazeau GA, Simpkins JW. 2000. Protective effect of estrogens against oxidative damage to heart and skeletal muscle in vivo and in vitro. Proceedings of the Society for Experimental Biology and Medicine 223:59-66. DOI: $10.1046 / \mathrm{j} .1525-1373.2000 .22308 . x$.

Porte C, Escartín E, García LM, Solé M, Albaigés J. 2000. Xenobiotic metabolising enzymes and antioxidant defences in deep-sea fish:relationship with contaminant body burden. Marine Ecology Progress Series 192:259-266. DOI: 10.3354/meps192259. 
497

498

499

500

501

502

503

504

505

506

507

508

509

510

511

512

513

514

515

516

517

518

519

520

521

522

523

524

525

526

527

Radovanović TB, Mitić SSB, Perendija BR, Despotović SG, Pavlović SZ, Cakić PD, Saičić ZS. 2010. Superoxide dismutase and catalase activities in the liver and muscle of barbel (Barbus Barbus) and its intestinal parasite (Pomphoryinchus laevis) from the danube river, serbia. Archives of Biological Sciences 62:97-105. DOI: 10.2298/ABS1001097R.

Román Rodríguez MJ, Hammann MG. 1997. Age and growth of totoaba, Totoaba macdonaldi (Sciaenidae), in the upper Gulf of California. Fishery Bulletin 95:620-628.

Sen AR, Mandal PK. 2016. Use of Natural Antioxidants in Muscle Foods and their Benefits in Human Health: An Overview. International Journal of Meat Science 7:1-5. DOI: 10.3923/ijmeat.2017.1.5.

Shumilin EN, Carriquiry JD, Camacho-Ibar VF, Sapozhnikov D, Kalmykov S, Sánchez A, Aguíiga-García S, Sapozhnikov YA. 2002. Spatial and vertical distributions of elements in sediments of the Colorado River delta and Upper Gulf of California. Marine Chemistry 79:113-131. DOI: 10.1016/S0304-4203(02)00059-2.

Smith SW, Latta LC, Denver DR, Estes S. 2014. Endogenous ROS levels in. BMC Evolutionary Biology 14:161. DOI: 10.1186/s12862-014-0161-8.

Soto-Mardones L, Marinone SG, Parés-Sierra A. 1999. Variabilidad espaciotemporal de la temperatura superficial del mar en el Golfo de California. Ciencias Marinas 25:1-30.

Speers-Roesch B, Ballantyne JS. 2005. Activities of antioxidant enzymes and cytochrome c oxidase in liver of Arctic and temperate teleosts. Comparative Biochemistry and Physiology - A Molecular and Integrative Physiology 140:487-494. DOI: 10.1016/j.cbpb.2005.02.014.

Suzuki K. 2000. Measurement of Mn-SOD and Cu, Zn-SOD. In: Taniguchi N, Gutteridge JMC eds. Experimental protocols for reactive oxygen and nitrogen species. Oxford: Oxford University Press, 91-95.

Tripathy A. 2016. Oxidative Stress, Reactive Oxygen Species (ROS) and Antioxidative Defense System, with Special Reference to Fish. International Journal of Current Research in Biosciences and Plant Biology 3:79-89. DOI: 10.20546/ijcrbp.2016.310.010.

True CD, Silva Loera A, Castro Castro N. 1997. Technical Notes: Acquisition of Broodstock of Totoaba macdonaldi: Field Handling, Decompression, and Prophylaxis of an Endangered Species. The Progressive Fish-Culturist 59:246-248. DOI: 10.1577/1548-8640(1497)059.

Valenzuela-Quiñonez F, Arreguín-Sánchez F, Salas-Márquez S, García-De León F, Garza J, Román-Rodríguez M, De-Anda-Montañez JA. 2015. Critically Endangered totoaba 
528

529

530

531

532

533

534

535

536

537

538

539

540

541

542

543

544

545

546

547

548

549

550

551

Totoaba macdonaldi: signs of recovery and potential threats after a population collapse. Endangered Species Research, 29: 1-11. http://www.int-res.com/abstracts/esr/v29/n1/p1$\underline{11 /}$

Viarengo A, Canesi L, Pertica M, Livingstone DR. 1991. Seasonal variations in the antioxidant defence systems and lipid peroxidation of the digestive gland of mussels. Comparative Biochemistry and Physiology Part C: Comparative Pharmacology 100:187-190. DOI: 10.1016/0742-8413(91)90151-I.

Viña J, Borrás C, Gambini J, Sastre J, Pallardó F V. 2005. Why Females Live Longer Than Males: Control of Longevity by Sex Hormones. Science of Aging Knowledge Environment 2005:pe17. DOI: 10.1126/sageke.2005.23.pe17.

Wiersma P, Selman C, Speakman JR, Verhulst S. 2004. Birds sacrifice oxidative protection for reproduction. Proc. R. Soc. Lond. B (Suppl.) 271:360-363. DOI: 10.1098/rsbl.2004.0171.

Wilhelm-Filho D, Torres MA, Tribess TB, Pedrosa RC, Soares CHL. 2001. Influence of season and pollution on the antioxidant defenses of the cichlid fish acará (Geophagus brasiliensis). Brazilian Journal of Medical and Biological Research 34:719-726. DOI: 10.1590/S0100879X2001000600004.

Wilson SM, Taylor JJ, Mackie TA, Patterson DA, Cooke SJ, Willmore WG. 2014. Oxidative Stress in Pacific Salmon (Oncorhynchus spp.) during Spawning Migration. Physiological and biochemical zoology 87:346-52. DOI: 10.1086/674798.

Wright J. 2017.Aquaculture gives endangered totoaba a fighting chance.

Zhang X, Wu T, Cai L, Zhu Y. 2007. Influence of fasting on muscle composition and antioxidant defenses of market-size Sparus macrocephalus. Journal of Zhejiang University. Science. B 8:906-911. DOI: 10.1631/jzus.2007.B0906. 
Figure 1

Totoaba (Totoaba macdonaldi) study area in the Gulf of California. 


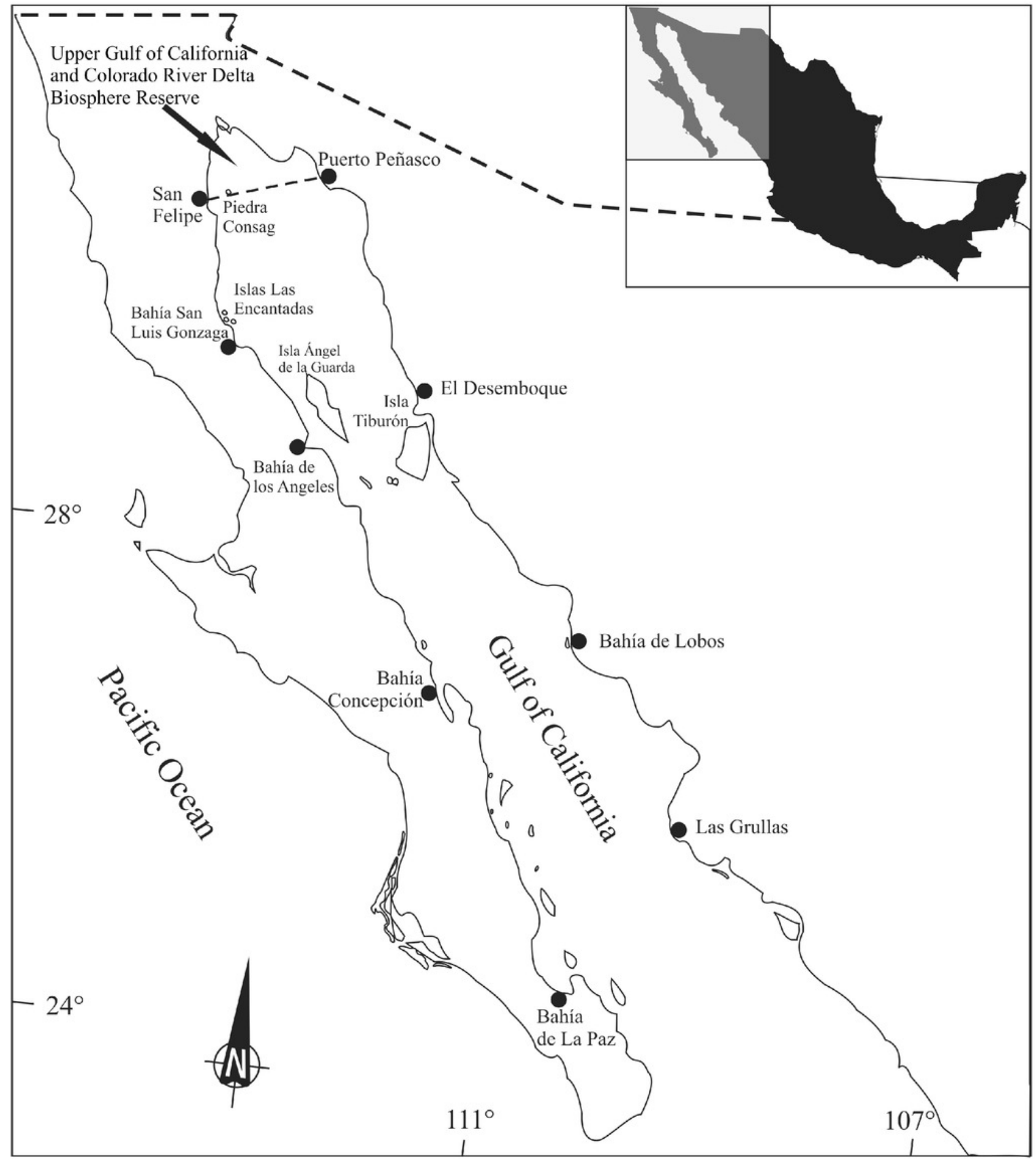


Figure 2

Number of samples of totoaba (Totoaba macdonaldi) collected in the Gulf of California during 2010-2013. FI, Immature females, FM, mature females, MI, immature males, MM, Mature males, $U$, Undifferentiated.

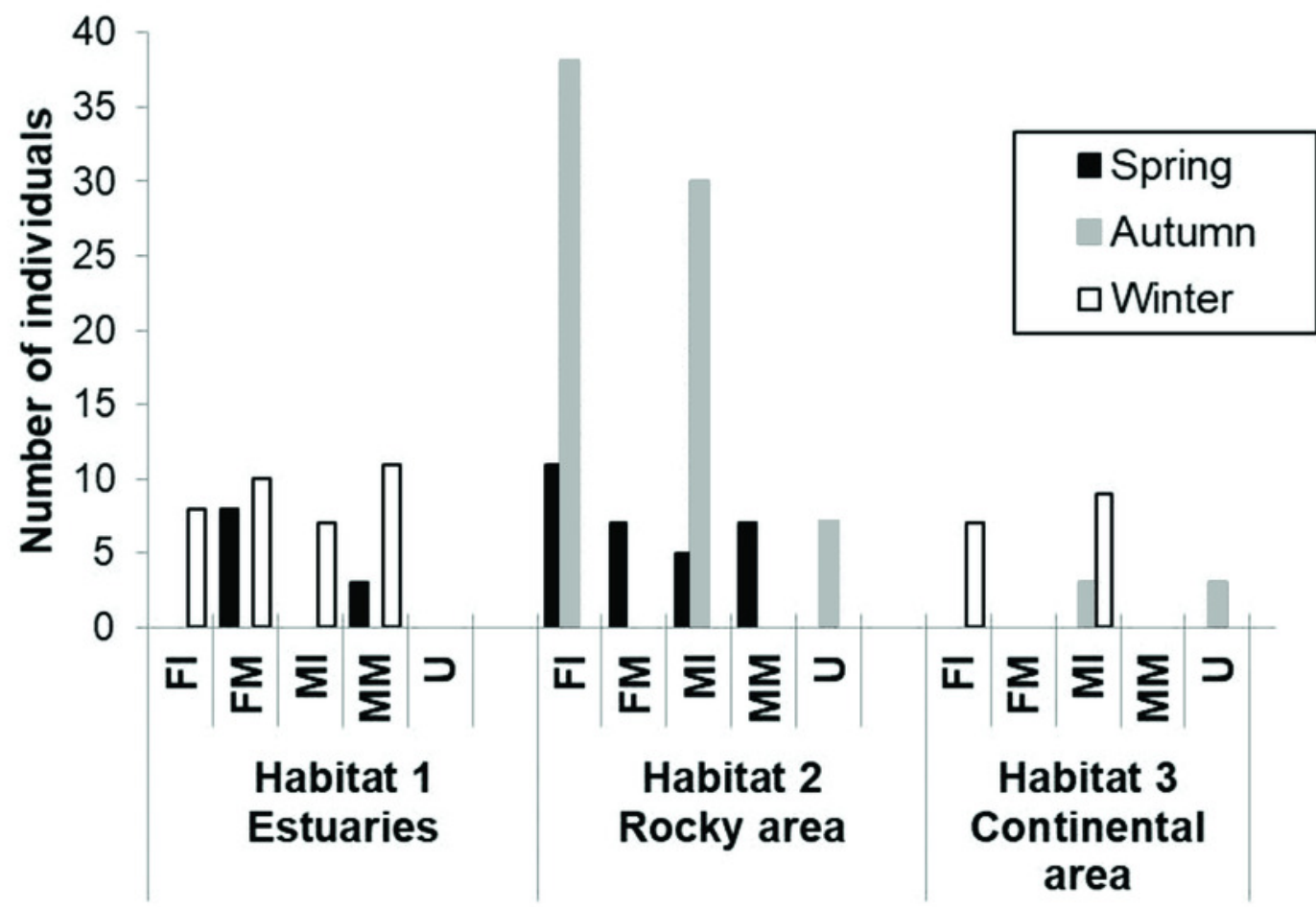


Figure 3

Residual analysis for superoxide radical $\left(\mathrm{O}_{2}{ }^{\circ}\right)$ production rate $(A-B)$ and lipid peroxidation (TBARS) levels (C-D). The best fit models were selected according to Aikaike's information criterion (AIC) and bayesian information criterion.
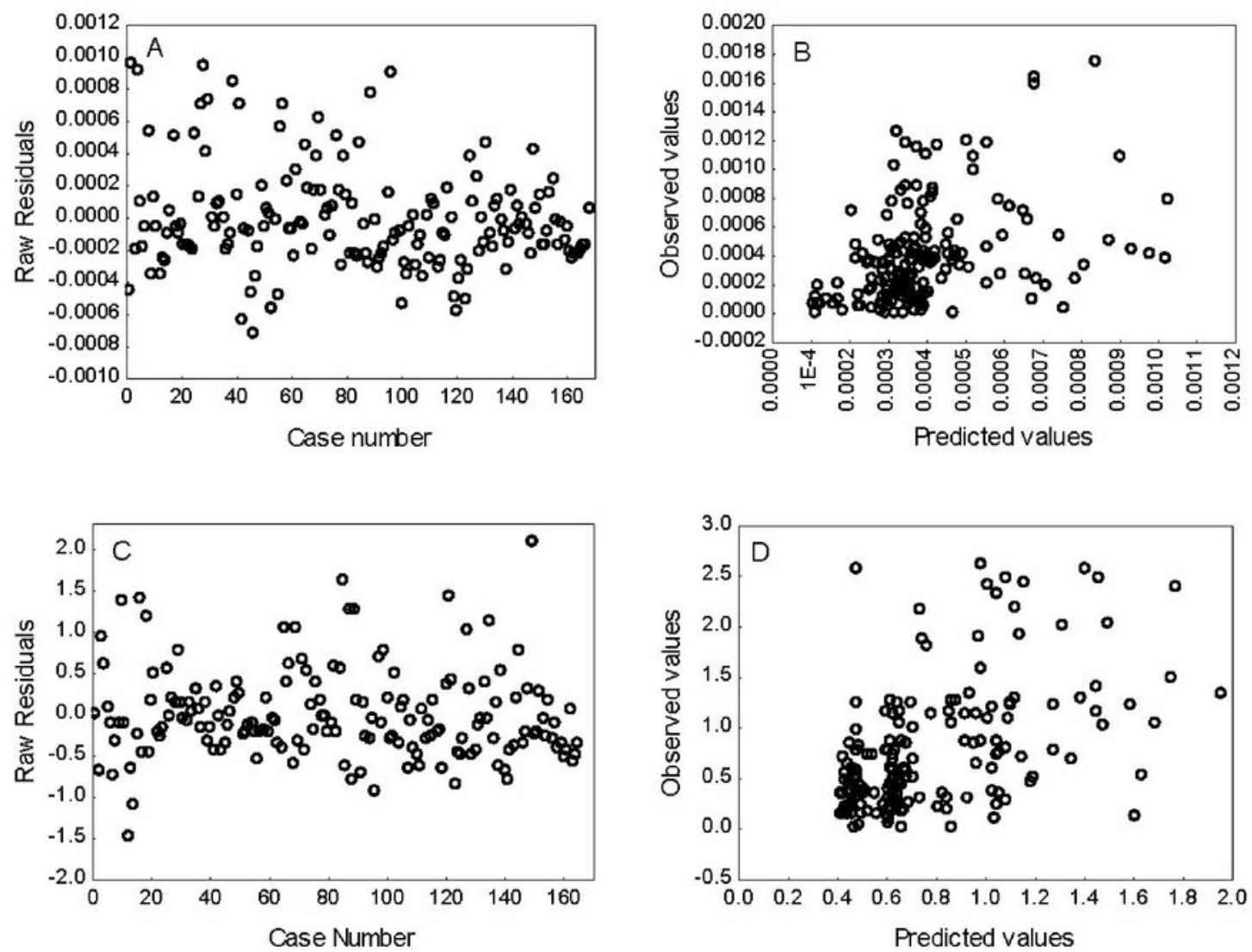


\section{Table $\mathbf{1}$ (on next page)}

Description of possible variables affecting the oxidative stress indicators in the muscle of Totoaba macdonaldi, captured in the Gulf of California, Mexico. 
1

\begin{tabular}{|c|c|c|}
\hline Variable & Type & Description \\
\hline Season & Categorical & $\begin{array}{l}\text { Spring: Spring 2010, 2011, } 2012 \\
\text { Autumn: Autumn 2010 and } 2011 \\
\text { Winter: Winter 2011, } 2013\end{array}$ \\
\hline Habitat & Categorical & $\begin{array}{l}\text { Habitat 1: } \\
\text { Estuaries zone, } \\
\text { South of San Felipe } \\
\text { Habitat 2: } \text { Rocky area, } \\
\text { Encantadas islands, } \\
\text { Consag island } \\
\text { Habitat 3: } \text { Continental area, } \\
\text { Lobos Bay, } \\
\text { El desemboque (Seris), } \\
\text { Las Grullas (Sinaloa) }\end{array}$ \\
\hline Sex/reproductive maturity status & Categorical & $\begin{array}{l}\text { FI: immature female } \\
\text { FM: mature female } \\
\text { MI: immature male } \\
\text { MM: mature male }\end{array}$ \\
\hline Superoxide dismutase (SOD) & Continuous & Enzymatic activity ( $\mathrm{U} \mathrm{mg}^{-1}$ protein) \\
\hline Catalase (CAT) & Continuous & Enzymatic activity ( $\mathrm{U} \mathrm{mg}^{-1}$ protein) \\
\hline Glutathione peroxidase (GPx) & Continuous & Enzymatic activity ( $\mathrm{U} \mathrm{mg}^{-1}$ protein) \\
\hline Glutathione reductase (GR) & Continuous & Enzymatic activity ( $\mathrm{U} \mathrm{mg}^{-1}$ protein) \\
\hline Glutathione S-transferase (GST) & Continuous & Enzymatic activity ( $\mathrm{U} \mathrm{mg}^{-1}$ protein) \\
\hline
\end{tabular}




\section{Table 2 (on next page)}

Oxidative stress indicators in muscle samples of totoaba (Totoaba macdonaldi) in the Gulf of California.

$\mathrm{O}_{2}{ }^{\circ}$, Superoxide radical production rate $\left(\mathrm{nmol} \mathrm{min} \mathrm{mg}^{-1}\right.$ protein); TBARS, concentration of

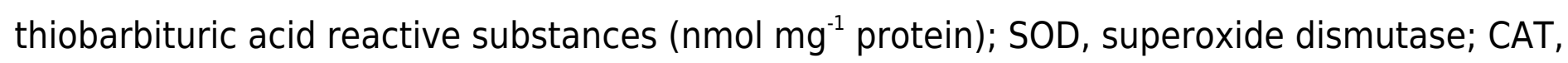
catalase; GPX, glutathione peroxidase; GR, glutathione reductase; GST, glutathione S-

transferase, antioxidant enzyme activities (Units $\mathrm{mg}^{-1}$ protein). Data are expressed as median and percentiles (25-75\%). FI: Immature females $(n=64)$, FM: Mature females $(n=25)$, MI: Immature males $(n=54)$, MM: Mature males $(n=21)$, U: Undifferentiated $(n=10)$. * Denotes significant differences between seasons. + Denotes significant differences between habitats. Different letters denote significant differences between sex/reproductive maturity status groups for each season and habitat. Level of statistical significance, $p<0.05$. 


\begin{tabular}{|c|c|c|c|c|c|c|c|}
\hline & & Variable & FI & FM & MI & MM & $\mathbf{U}$ \\
\hline \multirow{14}{*}{ 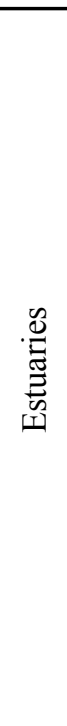 } & \multirow{7}{*}{$\stackrel{\infty}{\stackrel{\infty}{\Xi}}$} & $\mathbf{O}_{2}{ }^{\bullet-}$ & - & $0.00009(0.00007-0.0002)^{*}$ & - & $\begin{array}{c}0.00010(0.00008- \\
0.00011)^{+}\end{array}$ & - \\
\hline & & TBARS & - & $1.22(0.86-2.26)$ & - & $0.61(0.37-1.15)$ & - \\
\hline & & SOD & - & $8.43(6.10-16.37)$ & - & $8.15(6.33-24.43)$ & - \\
\hline & & CAT & - & $17.27(7.33-19.04) *$ & - & $8.65(4.50-21.82)$ & - \\
\hline & & GPx & - & $0.57(0.30-0.79) *$ & - & $0.07(0.05-0.31)^{+}$ & - \\
\hline & & GR & - & $0.20(0.07-0.36)$ & - & $0.11(0.09-0.32)$ & - \\
\hline & & GST & - & $0.03(0.02-0.05) *+$ & - & $0.02(0.01-0.06)$ & - \\
\hline & \multirow{7}{*}{ 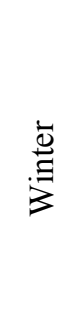 } & $\mathrm{O}_{2}{ }^{\bullet-}$ & $0.00012(0.00008-0.00018)$ & $0.0004(0.0003-0.0006) *$ & $0.0002(0.0001-0.0004)$ & $0.0005(0.0002-0.0006)$ & - \\
\hline & & TBARS & $0.23(0.15-0.83)$ & $0.73(0.44-1.15)$ & $0.39(0.30-0.93)$ & $0.73(0.49-1.31)$ & - \\
\hline & & SOD & $4.90(3.33-11.23)$ & $12.91(4.58-18.80)$ & $4.91(2.66-9.26)^{+}$ & $12.74(6.99-31.56)$ & - \\
\hline & & CAT & $3.40(1.89-5.40)$ & $4.45(2.42-5.59) *$ & $6.91(0.84-7.76)^{+}$ & $3.79(2.92-5.04)$ & - \\
\hline & & GPx & $0.10(0.10-0.15)$ & $0.12(0.08-0.21) *$ & $0.19(0.11-0.24)^{+}$ & $0.17(0.09-0.24)$ & - \\
\hline & & GR & $0.07(0.05-0.16)^{+}$ & $0.20(0.11-0.24)$ & $0.08(0.06-0.12)^{+}$ & $0.18(0.12-0.36)$ & - \\
\hline & & GST & $0.003(0.002-0.024)$ & $0.006(0.004-0.015) *$ & $0.004(0.002-0.015)^{+}$ & $0.011(0.005-0.040)$ & - \\
\hline \multirow{11}{*}{ 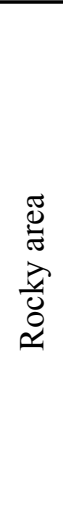 } & \multirow{7}{*}{ 品 } & $\mathrm{O}_{2}{ }^{--}$ & $0.0003(0.0002-0.0008)$ & $0.0001(0.0001-0.0008)$ & $0.0005(0.00005-0.0008)$ & $0.0003(0.0002-0.0013)^{+}$ & - \\
\hline & & TBARS & $0.88(0.59-1.09) *$ & $1.24(0.78-2.41)$ & $1.23(0.70-2.03)$ & $0.53(0.18-1.46)$ & - \\
\hline & & SOD & $6.72(4-8.09) *$ & $11.25(9.27-14.34)$ & $5.50(4.80-14.85)$ & $22.43(10.93-26.33)$ & - \\
\hline & & CAT & $6.40(3.09-11.86)$ & $5.00(3.83-10.58)$ & $11.26(7.76-36.61)$ & $14.94(6.17-21.45)$ & - \\
\hline & & GPx & $1.09(0.57-1.61) * \mathbf{b}$ & $0.18(0.11-0.48) \mathbf{a}$ & $0.56(0.37-1.34) \mathbf{b a}$ & $1.58(0.57-2.35)^{+} \mathbf{b}$ & - \\
\hline & & GR & $0.37(0.26-0.65)$ & $0.18(0.17-0.21)$ & $0.22(0.17-0.76)$ & $0.40(0.20-0.64)$ & - \\
\hline & & GST & $0.03(0.01-0.06)$ & $0.02(0.01-0.02)^{+}$ & $0.01(0.01-0.04)$ & $0.04(0.02-0.06)$ & - \\
\hline & \multirow{4}{*}{ 䒠 } & $\mathrm{O}_{2}^{\circ-}$ & $0.0004(0.0002-0.0005)$ & - & $0.0004(0.0002-0.0008)$ & - & $0.0004(0.0002-0.0009)$ \\
\hline & & TBARS & $0.44(0.24-0.74) *$ & - & $0.49(0.28-0.85)$ & - & $0.52(0.46-1.12)$ \\
\hline & & SOD & $11.71(6.62-19.83) *$ & - & $14.07(4.69-21.06)$ & - & $16.52(7.40-33)$ \\
\hline & & CAT & $8.49(5.25-16.67)$ & - & $8.00(5.52-15.93)$ & - & $40.88(21.83-53.16)$ \\
\hline
\end{tabular}




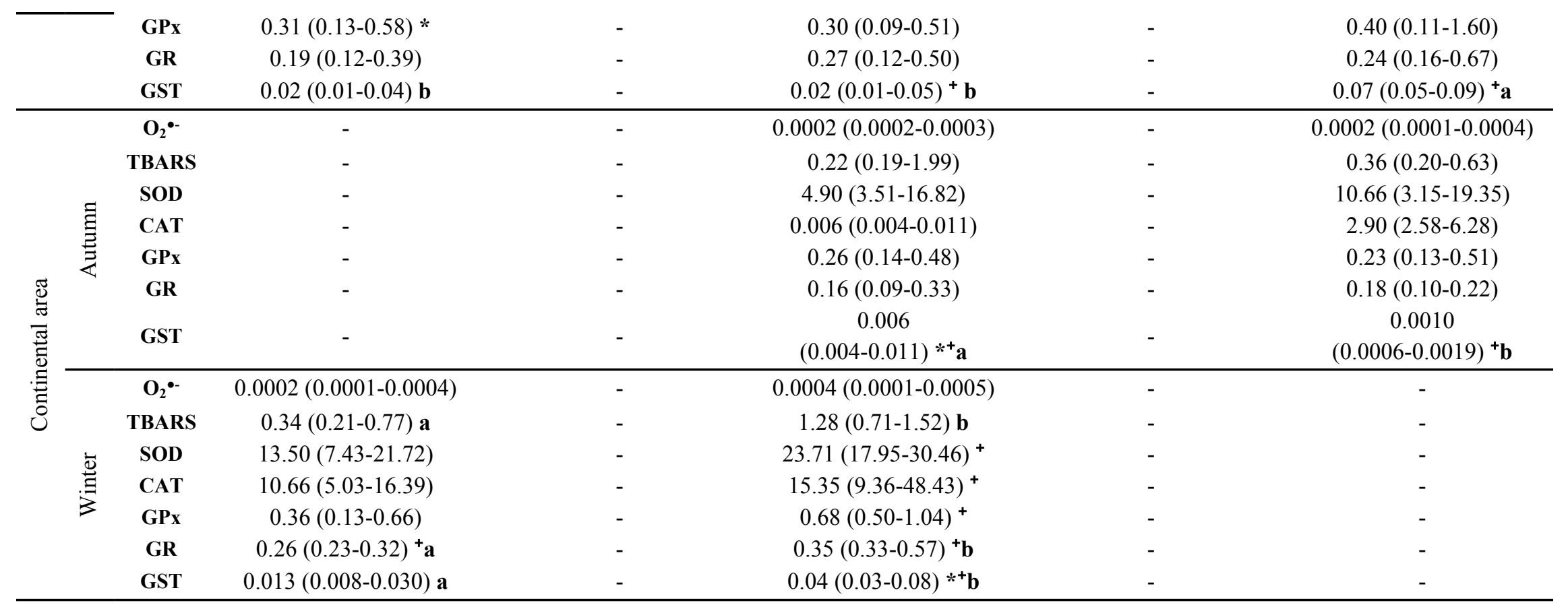




\section{Table 3 (on next page)}

Generalized linear models to describe the superoxide radical $\left(\mathrm{O}_{2}{ }^{\circ}\right)$ production rate and lipid peroxidation (TBARS) levels (results not shown) in muscle of the totoaba, Totoaba macdonaldi.

Models were constructed following the process shown. Best-fit models, shown in bold, were selected based on Akaike's information criterion (AIC), bayesian information criterion (BIC) and residual deviance (RD). SOD, superoxide dismutase; CAT, catalase; GPx, glutathione peroxidase; GR, glutathione reductase; GST, glutathione S-transferase, antioxidant enzyme activities (Units $\mathrm{mg}^{-1}$ protein). 
1

\begin{tabular}{lccc}
\hline Model superoxide radical $\left(\mathbf{O}_{\mathbf{2}}^{\left.\boldsymbol{*}^{-}\right)}\right.$production & AIC & BIC & RD \\
\hline Null & -2327 & -2321 & 152 \\
SOD & -2309 & -2299 & 141 \\
CAT & -2247 & -2238 & 143 \\
GPX & -2288 & -2279 & 145 \\
GR & $\mathbf{- 2 3 1 5}$ & $\mathbf{- 2 3 0 6}$ & $\mathbf{1 3 8}$ \\
GST & -2249 & -2239 & 144 \\
Habitat & -2332 & -2320 & 145 \\
Season & -2325 & -2313 & 150 \\
SeX/Maturity & -2321 & -2302 & 151 \\
& & & \\
GR + SOD & $\mathbf{- 2 2 9 1}$ & $\mathbf{- 2 2 7 8}$ & $\mathbf{1 3 2}$ \\
GR + CAT & -2233 & -2221 & 131 \\
GR + GPX & -2283 & -2271 & 136 \\
GR + GST & -2260 & -2247 & 134 \\
GR + Habitat & -2319 & -2303 & 133 \\
GR + Season & -2315 & -2299 & 136 \\
GR + Sex/Maturity & -2308 & -2286 & 138 \\
GR + SOD + CAT & & & \\
GR + SOD + GPX & -2207 & -2192 & 126 \\
GR + SOD + GST & -2259 & -2243 & 130 \\
GR + SOD + Habitat & -2233 & -2218 & 130 \\
GR + SOD + Season & -2297 & $\mathbf{- 2 2 7 8}$ & $\mathbf{1 2 5}$ \\
GR + SOD + Sex/Maturity & -2290 & -2272 & 130 \\
GR + SOD + Habitat + CAT & -2283 & -2259 & 132 \\
GR + SOD + Habitat + GPX & -2213 & -2192 & 119 \\
GR + SOD + Habitat + GST & -2265 & -2243 & 123 \\
GR + SOD + Habitat + Season & -2239 & -2218 & 123 \\
GR + SOD + Habitat + Sex/Maturity & -2299 & $-\mathbf{2 2 7 1}$ & $\mathbf{1 2 0}$ \\
GR + SOD + Habitat + Season + CAT & -2282 & -2235 & 124 \\
GR + SOD + Habitat + Season + GPX & -2221 & 116 \\
GR + SOD + Habitat + Season + GST & -2216 & -2186 & 113 \\
GR + SOD + Habitat + Season + Sex/Maturity & -2265 & -2234 & 119 \\
\hline
\end{tabular}




\section{Table 4 (on next page)}

Statistics of goodness of fit, parameter estimates and standard error (SE) from model variables in the final fitted general linear models (GLM).

$n$, number of data; RD, residual deviance; DF, degrees of freedom; AIC Akaike's information criterion. Values marked with * were significantly different $(p<0.05)$ from the intercept. 


\begin{tabular}{|c|c|c|c|c|c|}
\hline Models & \multicolumn{2}{|c|}{$\mathrm{O}_{2}^{\cdot-}$} & \multicolumn{3}{|c|}{ TBARS } \\
\hline Error & \multicolumn{2}{|c|}{ Gamma } & \multicolumn{3}{|c|}{ Gamma } \\
\hline Link & \multicolumn{2}{|c|}{$\log$} & \multicolumn{3}{|c|}{$\log$} \\
\hline $\mathrm{N}$ & \multicolumn{2}{|c|}{172} & \multicolumn{3}{|c|}{170} \\
\hline $\mathrm{RD}$ & \multicolumn{2}{|c|}{120} & \multicolumn{3}{|c|}{80} \\
\hline DF & \multicolumn{2}{|c|}{158} & \multicolumn{3}{|c|}{147} \\
\hline Level of effect & Estimate & SE & Level of effect & Estimate & SE \\
\hline Intercept & -8.584 & 0.134 & Intercept & $-0.674^{*}$ & 0.107 \\
\hline GR & $1.042 *$ & 0.328 & SOD & $0.015^{*}$ & 0.006 \\
\hline SOD & $0.017^{*}$ & 0.007 & CAT & 0.011 & 0.006 \\
\hline Estuaries & $-0.293^{*}$ & 0.175 & GST & 4.617 & 3.15 \\
\hline Rocky & $0.719 *$ & 0.147 & GPX & 0.020 & 0.139 \\
\hline Spring & $-0.411^{*}$ & 0.138 & Spring & $0.447^{*}$ & 0.099 \\
\hline Autumn & -0.028 & 0.124 & Autumn & $-0.385^{*}$ & 0.080 \\
\hline Habitat*Season & $-0.374 *$ & 0.173 & -- & -- & -- \\
\hline AIC & -22 & & & 18 & \\
\hline $\mathrm{BIC}$ & -22 & & & 20 & \\
\hline
\end{tabular}

2 